\title{
Gambaran Psikologis Remaja Selama Sekolah Dari Rumah Akibat Pandemi Covid-19
}

\author{
Paramita Estikasari $^{1}$, Sri Redatin Retno Pudjiati ${ }^{2 *}$ \\ ${ }^{1,2}$ Fakultas Psikologi, Universitas Indonesia \\ retno-pj@ui.ac.id
}

\begin{abstract}
Abstrak
Penyebaran COVID-19 di Indonesia berdampak pada penutupan sementara sekolah-sekolah di berbagai jenjang pendidikan termasuk Sekolah Menengah Pertama (SMP). Sekolah dari rumah secara daring menjadi alternatif pilihan agar kegiatan belajar mengajar tetap berjalan dengan risiko penyebaran COVID-19 yang minim pada remaja. Akan tetapi, beberapa penelitian menemukan bahwa kegiatan sekolah dari rumah membawa dampak negatif bagi remaja, khususnya remaja awal mengingat kebutuhan remaja untuk terlibat dalam aktivitas sosial sangat tinggi. Penelitian ini bertujuan untuk mengetahui kondisi psikologis remaja SMP selama melaksanakan kegiatan sekolah dari rumah secara daring akibat pandemi COVID-19. Jenis penelitian ini adalah penelitian deskriptif dengan metode survei online menggunakan media internet (internet surveys). Metode sampling yang digunakan adalah purposive sampling dengan jumlah sampel 143 partisipan ( $M_{a g e}=14 ; 57 \%$ perempuan). Hasil penelitian menunjukkan bahwa sekolah dari rumah membuat remaja SMP mengalami perasaan negatif seperti bosan (45,26\%), sedih (20,53\%), lelah (9,47\%), takut (1,58\%), khawatir (1,58\%), dan kecewa (2,63\%). Disisi lain, beberapa remaja menunjukkan perasaan positif seperti senang (16,32\%) dan nyaman (0,53\%). Perasaan negatif yang muncul terutama disebabkan oleh terbatasnya interaksi dengan teman dan banyaknya tuntutan tugas yang diberikan dari sekolah.
\end{abstract}

Kata kunci: kondisi psikologis; remaja; sekolah dari rumah; pandemi COVID-19

\begin{abstract}
The spread of COVID-19 in Indonesia has resulted in the temporary closure of schools at various levels of education including Junior High Schools (SMP). School from home is become an alternative choice so that teaching and learning activities can continue with the minimum spread of COVID-19 risk to adolescents. However, several studies have found that school from home have a negative impact on adolescent, especially early adolescent, given that they need to engage in social activities. The aim of this study is to look at the psychological condition of junior high school students during school from home due to COVID-19 pandemic. This type of research is a descriptive study with an online survey (internet surveys). The sampling method used was purposive sampling with a sample size of 143 participants $\left(M_{\text {age }}=14 ; 57 \%\right.$ woman). The results showed that school from home made adolescent experience negative feeling such us boredom (45,26\%), sadness (20,53\%), tiredness (9,47\%), fear (1,58\%), worry (1,58\%), adn disapointed $(2,63 \%)$. On the other hand, som adolescent showed positive feelings such as pleasure $(16,32 \%)$ and comfort (0,53\%). The negative events that arise are mainly due to limited interaction with friends and the large number of demands on assignments given from school.
\end{abstract}


Keywords: psychological condition, early adolescent, school from home, COVID-19 pandemic

\section{Pendahuluan}

Pada akhir Desember 2019, dunia dikejutkan dengan munculnya serangkaian kasus mirip pneumonia yang disebabkan oleh virus Corona jenis baru. Virus ini muncul pertama kali di provinsi Wuhan, China dan dengan cepat mengakibatkan wabah di seluruh dunia (Wu, Chen, \& Chan, 2020; Huang, dkk., 2020). Di Indonesia, hingga bulan Juni 2020 tercatat sebanyak 51.427 kasus positif COVID-19 (Kementerian Kesehatan Republik Indonesia, 2020). Penularan COVID-19 diketahui terjadi dari orang ke orang melalui droplet atau kontak langsung dengan penderita. Jika tidak ada pengendalian infeksi yang ketat serta alat pelindung diri yang memadai dapat sangat membahayakan (Wu, Chen, \& Chan, 2020). Guna mencegah penularan virus COVID-19, berbagai negara mulai menerapkan sistem lockdown dimana warga negaranya dilarang untuk melakukan aktivitas di luar rumah dan melakukan karantina mandiri (Leung, Lam, \& Cheng, 2020). Kegiatan mencuci tangan, menjaga jarak 2 meter, dan penggunaan masker, meskipun belum terbukti efektif untuk menangkal virus, tetapi tetap diberlakukan sebagai langkah awal untuk mencegah penularan virus COVID-19 (Leung, Lam, \& Cheng, 2020).

Di sektor anak, pemerintah Tiongkok memerintahkan wilayahnya untuk menutup sekolah. Diperkirakan lebih dari 220 juta anak-anak dan remaja harus tinggal di rumah (Wang, Zhang, Zhao, Zhang, \& Jyang, 2020). Menurut UNESCO, terhitung sejak 8 April 2020, sekolah telah ditangguhkan di 188 negara (Lee, 2020). Mengadopsi penanganan penyebaran virus COVID-19 dari beberapa negara, Indonesia telah menerapkan kebijakan tersebut dengan nama Pembatasan Sosial Berskala Besar (PSBB). Salah satu kebijakan PSSB yang berdampak pada aktivitas sehari-hari anak dan remaja adalah kegiatan belajar mengajar yang dialihkan menggunakan metode online atau dalam jaringan (daring). Sesuai dengan Surat Edaran Nomor 2 Tahun 2020 tentang Pencegahan dan Penanganan COVID-19 di Lingkungan Kemendikbud serta Surat Edaran Nomor 3 tahun 2020 tentang Pencegahan COVID-19 Pada Satuan Pendidikan, Kementerian Pendidikan dan Kebudayaan (Kemendikbud) bersama Gugus Tugas Percepatan Penanganan COVID-19, daerah yang berada di Zona kuning, oranye, dan merah, dilarang melakukan pembelajaran tatap muka dan harus tetap melanjutkan kegiatan belajar dari rumah (Kemendikbud, 2020).

Salah satu jenjang pendidikan yang paling merasakan dampak dari penangguhan sekolah adalah jenjang pendidikan Sekolah Menengah Pertama (SMP). Hal ini karena sebagai kelompok rentan, remaja sedang mengalami masa transisi yang sulit (Guessoum, dkk., 2020). Pada masa transisi, remaja sedang berada pada tahap pencarian identitas diri melalui teman-teman, komunitas sosial, kegiatan keagamaan, atau berbagai kegiatan kelompok lainnya dibandingkan di rumah bersama keluarganya (Marotz \& Allen, 2013). Interaksi dengan orang-orang di lingkungan sekitarnya dapat memberikan kesempatan bagi remaja untuk mencoba berbagai peran sampai menemukan peran yang cocok sebagai 
identitas dirinya (Miller, 2011). Remaja dipilih karena berdasarkan teori perkembangan Psikososial Erikson, tugas perkembangan remaja berelasi dan berorientasi pada teman. Pembatasan sosial akibat pandemi COVID-19 ini meningkatkan risiko munculnya distres psikologis yang lebih berat dan bertahan lama sehingga dampaknya hingga dewasa menjadi lebih parah (Wang, Zhang, Zhao, Zhang, \& Jiang, 2020).

Kebijakan penangguhan sekolah diambil oleh pemerintah karena dampak dari pandemi COVID-19 yang terjadi saat ini merupakan bentuk stresor atau trauma yang relatif baru untuk para profesional kesehatan mental (Kontoangelos, Economou, \& Papageorgiou, 2020). Beberapa penelitian telah menemukan dampak psikologis dari kebijakan karantina dan isolasi pada remaja seperti gangguan stres pasca trauma (PTSD), depresi, kecemasan, gangguan penyesuaian diri, dan gejala terkait dengan kesedihan (Kontoangelos, Economou, \& Papageorgiou, 2020; Wang, Wen, Dong, Liu, \& Cui, 2020; Liang, et.al. 2020; Guessoum, et.al. 2020 ). Meskipun kondisi tersebut dirasakan juga oleh orang dewasa, tetapi hal yang perlu menjadi perhatian adalah dampak negatif ini bertahan lebih lama pada anak-anak dan remaja dibandingkan dengan orang dewasa (Leung, Lam, \& Cheng, 2020). Selain itu, remaja perlu mendapat perlindungan ekstra karena mereka mudah mengalami perasaan khawatir, cemas, dan takut sehingga lebih rentan terpapar COVID-19.

Meskipun langkah pemerintah untuk melaksanakan sekolah dari rumah merupakan tindakan yang tepat guna mencegah penyebaran virus COVID-19 di sektor anak, tetapi terganggunya rutinitas sehari-hari anak seperti terbatasnya kegiatan di luar ruangan dan terhambatnya interaksi dengan teman seusianya selama wabah meningkatkan risiko distress psikologis pada remaja (Lee, 2020; Leung, Lam, \& Cheng, 2020; Wang, Zhang, Zhao, Zhang, \& Jiang, 2020). Dampak negatif ini muncul karena remaja harus menghabiskan sebagian besar waktunya dengan beraktivitas secara online dan memiliki sedikit waktu untuk berkegiatan di luar ruangan seperti olahraga, kegiatan ekstrakurikuler, atau berkumpul dengan teman sebaya.

Selain itu, selama belajar dari rumah, ditemukan banyak stressor yang berkontribusi meningkatkan distress psikologis anak dan remaja, diantaranya adalah lamanya durasi karantina mandiri, ketakutan akan terkena infeksi, rasa frustrasi dan bosan, informasi yang tidak akurat, kurangnya kontak langsung dengan teman dan guru, kurangnya privasi di rumah, masalah keuangan keluarga, dan peningkatan waktu akses ke media sosial/internet (Wang, Zhang, Zhao, Zhang, \& Jiang, 2020; Guessoum, dkk., 2020). Selain itu, daily hassles atau gangguan sehari-hari dari sekitar sangat berperan dalam meningkatkan distres psikologis pada remaja seperti tuntutan akademik, konflik dengan teman, konflik orang tua, kebisingan di lingkungan, serta sumber daya yang tidak dapat terpenuhi. Namun demikian, banyak remaja yang tidak menyadari bahwa gangguan-gangguan kecil tersebut dapat berdampak negatif pada perkembangan psikologis mereka (Allen, dkk., 1995).

Penelitian terbaru menemukan bahwa selama masa karantina dan social distancing, internet dan media sosial seperti video chatting, blogging, atau game online 
terbukti dapat mengurangi dampak negatif yang ditimbulkan pada remaja. Media sosial dan internet dapat meningkatkan kesempatan anak dan remaja untuk tetap terhubung dengan keluarga dan teman setiap saat. Media sosial membuat mereka merasa lebih tehubung dengan teman-teman dan membantu mereka untuk mengakses dukungan sosial selama masa-masa sulit. Selain itu, komunikasi online dapat memperbaiki perasaan negatif setelah remaja mengalami social exclusion (Orben, Tomova, \& Blackmore, 2020)

Meskipun demikian, penelitian yang dilakukan oleh Malley, Langton, Anderson, Sneddon dan Bruce (1996) menemukan bahwa komunikasi tatap muka memberikan kesan yang berbeda dibandingkan dengan komunikasi melalui video call atau audio call. Pada komunikasi menggunakan media, mereka mengetahui bahwa lawan bicara tidak benar-benar hadir saat itu. Kondisi tersebut memunculkan perasaan kurangnya "social presence" dari lawan bicara. Selain itu, efek dari video image atau video size yang kurang baik sehingga informasi nonverbal seperti gesture tidak seluruhnya terlihat dan terkadang diabaikan. Communication gaze atau kesadaran untuk mengkomunikasikan percakapan dua arah seperti siapa yang akan menjadi fokus percakapan saat ini, siapa yang mendapat giliran berbicara selanjutnya pun menjadi terhambat. Selanjutnya, efek dari keterlambatan dari sinyal video sehingga respons lawan bicara tidak dapat langsung diberikan. Kondisikondisi tersebut menyebabkan komunikasi 2 arah menjadi kurang lancar. Lebih lanjut, bagi anak dan remaja internet juga meningkatkan risiko gangguan mental seperti kecanduan game (Giallinardo, dkk., 2020). Selain itu, pengguna pasif internet dan media sosial seperti melihat beranda milik akun orang lain dapat menurunkan kesejahteraan seseorang karena dapat meningkatkan perasaan iri dan perbandingan sosial (Orben, Tomova, \& Blackmore, 2020)

Berbagai dampak negatif dari penangguhan sekolah akibat pandemi COVID-19 perlu mendapatkan perhatian. Sebagai upaya pencegahan, pemerintah perlu mengidentifikasi kondisi psikologis serta hambatan-hambatan yang dirasakan remaja Indonesia ketika melaksanakan kegiatan sekolah dari rumah akibat pandemi COVID-19. Harapannya pemerintah dan orang-orang terdekat dengan remaja dapat memberikan upaya pencegahan atau penanganan yang tepat untuk mencegah timbulnya masalah psikologis yang lebih berat bagi remaja di masa depan. Penelitian ini bertujuan untuk menggambarkan kondisi psikologis remaja SMP serta meninjau berbagai sumber hambatan yang dialami remaja SMP selama melaksanakan sekolah dari rumah akibat pandemic COVID-19 di Indonesia. Penelitian ini perlu dilakukan sebagai upaya preventif pada kondisi psikologis remaja agar tidak terjadi dampak negatif yang lebih parah dimasa depan.

\section{Metode}

Penelitian ini merupakan penelitian deskriptif untuk menggambarkan dan menganalisa berbagai kondisi yang terjadi pada remaja awal akibat pandemi COVID-19 di Indonesia. Penelitian deskriptif juga dapat digunakan sebagai penelitian pendahuluan 
atau preliminary study untuk memahami fenomena baru. Peneliti mengumpulkan data dengan metode survei online menggunakan media internet (internet surveys). Jenis pertanyaan yang diajukan adalah pertanyaan terbuka sehingga partisipan penelitian mendapatkan fleksibilitas dalam menjawab dan memungkinkan partisipan penelitian untuk mengungkapkan pikiran atau pendapat dengan sebenarnya. Pertanyaan-pertanyaan di dalam kuesioner disusun berdasarkan faktor-faktor yang berperan pada gangguan sehari-hari atau daily hassles remaja (Allen, dkk., 1995).

Partisipan dalam penelitian ini dipilih dengan menggunakan teknik purposive sampling berdasarkan kriteria yang ditentukan peneliti, yaitu remaja SMP berusia 12-16 tahun $\left(\mathrm{M}_{\mathrm{age}}=14 ; 57 \%\right.$ perempuan) yang melakukan sekolah dari rumah secara online. Sebanyak 143 partisipan (61 laki-laki dan 82 perempuan) ikut berpartisipasi dalam penelitian ini. Data dianalisis secara deskriptif menggunakan frekuensi untuk menggambarkan dan menganalisa kondisi psikologis remaja selama belajar dari rumah akibat pandemi COVID-19.

\section{Hasil}

Data demografis dari 143 partisipan (61 laki-laki dan 82 perempuan) siswa-siswi remaja SMP ditampilkan pada Tabel 1. Rentang usia partisipan antara 12-16 tahun dengan rata-rata usia 14,10 tahun. Partisipan paling banyak adalah remaja berusia 14 tahun yaitu $55(38,46 \%)$. Frekuensi jenis kelamin partisipan terbanyak adalah jenis kelamin perempuan yaitu 82 (57,34\%), dan berada di kelas VII sebanyak $72(50,35 \%)$.

Dibandingkan dengan sekolah dari rumah, sebanyak 129 (90,21\%) partisipan merasa lebih senang sekolah seperti biasa karena dapat berinteraksi dengan teman dan guru di sekolah, mendapatkan penjelasan materi secara langsung dengan metode yang tidak monoton, tugas yang diberikan oleh guru lebih sedikit, dan situasi yang lebih kondusif untuk belajar. Selanjutnya, partisipan yang memilih sekolah dari rumah $(9,79 \%)$ merasa bahwa sekolah di rumah lebih santai, aman, dan nyaman untuk mengerjakan tugas-tugas tanpa dibatasi waktu yang ketat. Selain itu sekolah dari rumah membuat partisipan mendapat waktu istirahat yang cukup. Sekolah dari rumah juga dianggap praktis karena dapat mencari materi-materi secara online apabila kurang memahami materi-materi sekolah.

Tabel 2. Menampilkan frekuensi perasaan yang dirasakan partisipan. Sebagian besar partisipan menyebutkan lebih dari 1 perasaan sehingga diperoleh hasil sebanyak 190 total perasaan yang muncul dari 143 partisipan. Berdasarkan indikator kualitatif terkait dengan perasaan partisipan selama kegiatan sekolah dari rumah, bosan $(44,76 \%)$, sedih $(23,08 \%)$ dan senang $(19,58 \%)$ adalah perasaan yang paling banyak dialami selama sekolah dari rumah. Lebih detail, jenis perasaan selama sekolah dari rumah dan penyebabnya ditampilkan di Tabel 2. Delapan perasaan muncul di dalam hasil penelitian. Perasaan negatif memiliki frekuensi yang lebih banyak dibandingkan dengan perasaan positif. Perasaan negatif seperti rasa bosan, sedih, dan kecewa yang dirasakan partisipan 
umumnya disebabkan oleh kurang atau terbatasnya interaksi dengan teman maupun guru, tugas yang terlalu banyak, kesulitan untuk memahami materi, dan kondisi rumah yang kurang kondusif untuk belajar.

Tabel 1. Distribusi Partisipan berdasarkan demografis $(\mathrm{N}=143)$

\begin{tabular}{llll}
\hline Variabel & Kategori & Jumlah $(\mathrm{n})$ & Persentase \\
\hline \multirow{4}{*}{ Usia } & 12 & 6 & $4,20 \%$ \\
& 13 & 30 & $20,98 \%$ \\
\multirow{3}{*}{ Jenis Kelamin } & 14 & 55 & $38,46 \%$ \\
& 15 & 47 & $32,87 \%$ \\
\multirow{2}{*}{ Kelas } & 16 & 5 & $3,50 \%$ \\
\multirow{2}{*}{ Sekolah yang disukai } & Laki-laki & 61 & $42,66 \%$ \\
& Perempuan & 82 & $57,34 \%$ \\
& VII & 72 & $50,35 \%$ \\
& VIII & 12 & $8,39 \%$ \\
& IX & 59 & $41,26 \%$ \\
& Sekolah seperti biasa & 129 & $90,21 \%$ \\
\hline
\end{tabular}

Perasaan negatif lainnya seperti takut $(2,10 \%)$ dan kecewa $(2,10 \%)$ dilatarbelakangi oleh keterbatasan untuk berhubungan dengan orang lain, yaitu guru dan teman. Pada akhirnya sebagian besar perasaan negatif yang dirasakan oleh partisipan merupakan dampak dari interaksi sosial yang terhambat.

Selain perasaan negatif, beberapa partisipan juga memberikan respon perasaan positif yaitu 31 partisipan merasa senang $(19,58 \%)$ dan 1 partisipan merasa nyaman $(0,70 \%)$. Terakhir, 4 partisipan $(2,80 \%)$ merasa netral atau biasa saja selama melaksanakan sekolah dari rumah. Remaja yang memberikan respon perasaan positif meskipun harus melaksanakan sekolah dari rumah karena partisipan dapat bangun tidur lebih siang, lebih banyak waktu untuk berkumpul dengan keluarga dan dapat melakukan aktivitas sekolah, belajar, ataupun mengerjakan tugas dengan santai.

Tabel 2. Distribusi Perasaan Partisipan (N=190)

\begin{tabular}{|c|c|c|c|}
\hline Jenis Perasaan & Jumlah (n) & Persentase & Contoh Alasan \\
\hline Bosan & 86 & $45,26 \%$ & $\begin{array}{l}\text { Tidak bisa bermain/bertemu/berinteraksi } \\
\text { dengan teman atau guru } \\
\text { Tidak ada kegiatan } \\
\text { Pembelajaran hanya diberikan tugas-tugas }\end{array}$ \\
\hline Sedih & 39 & $20,53 \%$ & $\begin{array}{l}\text { Tidak bisa bertanya kepada guru ketika } \\
\text { kesulitan mengerjakan soal Tidak dapat keluar } \\
\text { rumah } \\
\text { Kesulitan/butuh waktu lebih lama untuk } \\
\text { memahami materi pelajaran }\end{array}$ \\
\hline Lelah & 18 & $9,47 \%$ & $\begin{array}{l}\text { Banyak diberi tugas berupa materi-materi } \\
\text { yang belum diajarkan }\end{array}$ \\
\hline
\end{tabular}




\begin{tabular}{|c|c|c|c|}
\hline & & & Kondisi rumah lebih berisik daripada sekolah \\
\hline \multirow[t]{2}{*}{ Takut } & 3 & $1,58 \%$ & Takut tidak bisa lagi bertemu dengan guru \\
\hline & & & $\begin{array}{l}\text { Takut mengenai masa depan (jenjang } \\
\text { pendidikan yang lebih tinggi }\end{array}$ \\
\hline Khawatir & 3 & $1,58 \%$ & Terdapat virus Covid-19 \\
\hline Kecewa & 5 & $2,63 \%$ & Tidak bisa bertemu teman \\
\hline Nyaman & 1 & $0,53 \%$ & Bisa belajar di rumah \\
\hline \multirow[t]{4}{*}{ Senang } & 31 & $16,32 \%$ & Bisa bangun siang \\
\hline & & & Lebih banyak waktu berkumpul dengan \\
\hline & & & keluarga \\
\hline & & & $\begin{array}{l}\text { Bisa belajar sambil makan, minum, dan } \\
\text { berbaring }\end{array}$ \\
\hline Biasa saja & 4 & $2,11 \%$ & Bisa belajar dengan tenang. \\
\hline
\end{tabular}

Tabel 3. menampilkan distribusi sumber hambatan yang dialami partisipan selama sekolah dari rumah secara daring. Ditinjau dari faktor-faktor daily hassles atau gangguan yang sehari-hari yang dialami remaja, 54 partisipan mengeluhkan hambatan karena gangguan sekolah atau school hassles (36,48\%), 48 partisipan karena hambatan terkait dengan sumber daya seperti jaringan/ kuota/ alat komunikasi (32, 43\%), 12 partisipan karena teman sebaya atau peer hassles seperti kurangnya interaksi sehingga menimbulkan rasa kesepian $(8,10 \%), 11$ partisipan karena faktor keluarga atau family hassles, dan 6 orang merasakan gangguan dari lingkungan atau neighborhood hassles. Selanjutnya, sebanyak 17 partisipan tidak merasakan adanya hambatan selama sekolah dari rumah.

Tabel 3. Distribusi Sumber Hambatan Selama Sekolah Dari Rumah N=148

\begin{tabular}{|c|c|c|c|}
\hline Sumber Hambatan & Jumlah (n) & Persentase & Contoh Hambatan \\
\hline School hassles & 54 & $36,48 \%$ & $\begin{array}{l}\text { Penjelasan atau instruksi tugas tidak jelas, } \\
\text { sehingga sulit untuk memahami materi } \\
\text { dan mengerjakannya tugas } \\
\text { Terlalu banyak tugas }\end{array}$ \\
\hline Resource hassles & 48 & $32,43 \%$ & $\begin{array}{l}\text { Paket dan kuota habis dan sinyal tidak } \\
\text { baik } \\
\text { Tidak memiliki handphone (harus } \\
\text { menyewa handphone) }\end{array}$ \\
\hline Peer hassles & 12 & $8,10 \%$ & $\begin{array}{l}\text { Tidak dapat bertemu dengan teman } \\
\text { Tidak dapat berdikusi tentang tugas } \\
\text { dengan teman }\end{array}$ \\
\hline Family hassles & 11 & $7.43 \%$ & $\begin{array}{l}\text { Kurang waktu karena harus membantu ibu } \\
\text { di rumah } \\
\text { Dilarang keluar rumah } \\
\text { Kurang bebas melakukan apapun } \\
\text { Tidak diberi uang saku }\end{array}$ \\
\hline Neighborhood hassles & 6 & $4,05 \%$ & $\begin{array}{l}\text { Menjadi tidak fokus saat belajar } \\
\text { Tidak tenang untuk belajar }\end{array}$ \\
\hline Tidak ada masalah & 17 & $11,18 \%$ & Tidak ada masalah \\
\hline
\end{tabular}




\section{Pembahasan}

Sejak virus COVID-19 tersebar ke seluruh dunia, banyak negara menerapkan kebijakan lockdown, karantina, atau isolasi wilayah yang menyebabkan aktivitas seharihari terbatas. Berdasarkan penelitian terbaru, kebijakan tersebut menimbulkan berbagai dampak negatif pada kesehatan psikologis khususnya bagi remaja. Penelitian ini dilakukan untuk mengidentifikasi kondisi psikologis remaja awaldi Indonesia selama melaksanakan kegiatan sekolah dari rumah akibat pandemi COVID-19. Berdasarkan penelitian, ditemukan hasil bahwa selama melaksanakan kegiatan sekolah secara daring, remaja mengalami berbagai perasaan negatif serta hambatan-hambatan yang mengganggu kegiatan belajar.

Pada studi ini, hasil menunjukkan distribusi perasaan pada remaja awal terdampak COVID-19 selama sekolah dari rumah cocok dengan penelitian yang dilakukan sebelumnya meskipun dengan frekuensi yang berbeda (Wang, Zhang, Zhao, Zhang, \& Jiang, 2020; Guessoum, dkk., 2020; Saurabh dan Rajan, 2020). Sebagai contoh, penelitian yang dilakukan oleh Saurabh dan Rajan (2020) pada anak dan remaja berusia 9-18 tahun $(\mathrm{N}=121)$ menunjukkan hasil perasaan yang paling banyak muncul adalah cemas sebanyak 83 partisipan $(68,59 \%)$, tidak berdaya sebanyak 80 partisipan $(66,11 \%)$ dan takut sebanyak 75 partisipan (61.98\%). Pada penelitian ini, dalam menanggapi kegiatan sekolah dari rumah, perasaan terbanyak didominasi oleh perasaan negatif seperti rasa bosan sebanyak 86 partisipan $(45,26)$, sedih sebanyak 39 partisipan $(20,53 \%)$, dan lelah sebanyak 18 partisipan $(9,47 \%)$. Selama sekolah dari rumah, hanya 1,58\% remaja yang merasa takut dan khawatir. Umumnya, perasaan negatif disebabkan oleh interaksi yang terbatas dan kegiatan akademik yang tidak berjalan dengan lancar. Lebih lanjut, remaja merasa bosan dan sedih karena tidak dapat bertemu dan bermain dengan temannya, merasa hanya memiliki sedikit kegiatan yang dapat dilakukan selama di rumah, serta kegiatan belajar mengajar secara daring menyebabkan remaja merasa lelah karena tugastugas yang harus diselesaikan menjadi lebih banyak.

Masa remaja awal merupakan periode transisi yang kritis dan penuh dengan ketidakpastian. Umumnya, remaja menolak diperlakukan seperti anak-anak, namun belum siap untuk berpikir layaknya orang dewasa (Marotz, 2013). Kebutuhan untuk berinteraksi menjadi ciri khas perkembangan remaja awal dengan keyakinan bahwa persahabatan merupakan hal yang sangat penting (De Goede, et. al. 2009). Mereka mulai banyak berpartisipasi dalam berbagai kegiatan ekstrakurikuler seperti klub olahraga, berkumpul di cafe, mengobrol lewat ponsel dan blog, atau terlibat dalam platform jejaring sosial lainnya. Remaja memiliki semangat yang tinggi untuk belajar, mencari tahu, dan berusaha untuk berdaya serta membuat perbedaan-perbedaan di lingkungannya (Marotz, 2013).

Bertolak belakang dengan kebutuhan remaja, situasi pandemi saat ini mengharuskan mereka untuk melakukan social distancing atau jaga jarak. Kegiatan sekolah secara daring, menyebabkan remaja lebih banyak menghabiskan waktu di rumah 
tanpa berinteraksi langsung dengan orang lain di sekitar lingkungannya. Studi menemukan bahwa remaja yang kontak sosialnya dibatasi mengalami peningkatan rasa kesepian (Loades, dkk., 2020). Kesepian merupakan pengalaman emosional yang menyakitkan dari adanya kesenjangan antara hal dibutuhkan dan diinginkan oleh remaja. Meskipun isolasi sosial tidak selalu identik dengan rasa kesepian, indikasi awal dalam konteks pandemi COVID-19 menunjukkan bahwa lebih dari sepertiga remaja melaporkan tingkat kesepian yang tinggi (Loades, dkk., 2020).

Terisolasi secara sosial dan kesepian membawa dampak lanjutan bagi remaja, yaitu peningkatan distress psikologis, dimana kesepian dapat menyebabkan rendahnya self-esteem, menyalahkan diri, merendahkan diri, dan depresi (Jakcson \& Cochran, 1991; Enec, at. Al., 2020; Saurabh \& Ranjan, 2020). Dampak dari peningkatan distres psikologis selama masa karantina adalah laporan dari orang tua mengenai perubahan emosi dan perilaku anak-anak seperti sulit berkonsentrasi, bosan, lekas marah, gelisah, gugup, kesepian, tidak nyaman, dan khawatir (Orgiles, Morales, Delveccio, Mazzezchi, \& Espada, 2020). Selain itu, perasaan seperti kebingungan, ketakutan, kemarahan, kesedihan, mati rasa, dan kecemasan terkait dengan insomnia juga dirasakan oleh remaja (Orben, Tomova, Blakemore, 2020).

Salah satu cara untuk menjaga kondisi psikologis remaja selama sekolah dari rumah adalah dengan menyediakan akses informasi dan komunikasi melalui media sosial atau media komunikasi online. Penelitian terbaru telah menemukan dampak positif penggunaan media sosial bagi remaja, salah satunya adalah memperbaiki perasaan negatif remaja (Orben, Tomova, \& Blackmore, 2020). Remaja sangat mengandalkan media sosial untuk tetap terhubung dengan teman dan keluarga (Jackson, dkk., 2010). Akan tetapi, muncul masalah baru akibat penggunaan gadget yang tidak dibatasi. Manajemen waktu yang buruk seperti kesulitan untuk menahan keinginan bermain handphone atau games cukup banyak dialami oleh remaja. Media sosial memang memainkan peran penting yang memungkinkan anak-anak yang dikarantina untuk memenuhi kebutuhan interaksi mereka yang tinggi. Akan tetapi, dampak negatif seperti kurangnya rentang perhatian atau inatensi, peningkatan penggunaan layar atau screen time, dan kecanduan games juga dilaporkan selama masa karantina (Imran, dkk., 2020; Giallinardo, dkk., 2020; Orgiles, Morales, Delveccio, Mazzezchi, \& Espada, 2020). Oleh sebab itu, orang tua dan pengasuh perlu memberikan pengawasan terhadap penggunaan gadget pada remaja untuk mencegah dampak negatif lainnya.

Lebih lanjut, di dalam penelitian ini, remaja tidak hanya memberikan respon perasaan negatif. Ditemukan bahwa sebagian besar remaja memberikan respon perasaan positif yaitu senang (16,32\%). Perasaan senang menduduki peringkat ketiga setelah bosan dan sedih. Partisipan yang merasa senang selama periode karantina mengemukakan bahwa bangun lebih siang, dapat melaksanakan kegiatan sekolah dari rumah tanpa aturan seperti belajar sambil makan, minum, dan berbaring merupakan hal yang menyenangkan. Mereka merasa lebih bebas dan santai dalam menjalani kegiatan sekolah dari rumah. 
Mereka juga merasa senang karena dapat lebih banyak menghabiskan waktu dengan keluarganya.

Berdasarkan penelitian yang telah dilakukan sebelumnya, perasaan positif selama pandemi COVID-19 pada remaja dapat terjadi karena pada situasi karantina, jaga jarak, ataupun sekolah dari rumah memiliki pengaruh yang berbeda-beda pada remaja (Orben, Tomova, \& Blakemore, 2020). Remaja yang tinggal dalam keluarga yang menjalankan peran dan fungsinya dengan baik dan remaja yang memiliki hubungan yang positif dengan orang tua atau pengasuh mungkin tidak terlalu terpengaruh dengan kebijakan tersebut dibandingkan dengan remaja yang tidak memiliki hubungan keluarga yang positif atau remaja yang tinggal sendiri (Orben, Tomova, \& Blakemore, 2020). Meskipun demikian, relasi orang tua dan anak pada masa pandemi COVID-19 ini menarik untuk dikaji lebih mendalam mengingat pengaruh keluarga pada remaja umumnya lebih rendah dibandingkan dengan pengaruh teman sebaya (De Goede, et. al. 2009). Oleh sebab itu, pengaruh hubungan antara orang tua pada kondisi psikologis remaja yang merasakan perasaan positif pada konteks pandemi COVID-19 ini perlu diteliti lebih lanjut. Terkait dengan aturan, Fleming (2005) di dalam penelitiannya menemukan bahwa usaha untuk memperjuangkan otonomi diri telah muncul pada remaja awal. Seiring dengan pertambahan usia, tuntutan otonomi ini menjadi semakin tinggi. Remaja awal menganggap diri mereka sudah cukup dewasa dan merasa bahwa aturan dan batasan terlalu membatasi dan mengekang. Oleh sebab ibu, kegiatan sehari-hari yang berlawanan dengan rutinitas seperti bangun pagi untuk bersiap-siap ke sekolah, tidak boleh makan, minum, dan tidur di dalam kelas selama pelajaran berlangsung membawa dampak positif bagi beberapa remaja.

Tugas perkembangan lain pada remaja selain meningkatnya kebutuhan otonomi adalah tekanan untuk berhasil secara akademik. Memasuki usia remaja, mereka mulai bermimpi dan membayangkan mengenai pilihan-pilihan karir di masa depan. Untuk mencapai tujuan karir, prestasi akademik menjadi penting bagi remaja karena dalam masyarakat prestasi akademik serta kegagalan akademik dinilai dapat menentukan karir akademik masa depan individu dan peluang kerjanya (Rana \& Mahmood, 2010). Studi menunjukkan bahwa kompetensi akademis memiliki pengaruh penting pada konsep diri remaja dan berkontribusi pada kebahagiaan, kenyamanan, dan kesejahteraan individu (Rathore \& Sangwan, 2015). Kondisi tersebut sesuai dengan hasil di dalam penelitian ini dimana faktor akademik menjadi faktor kedua yang berperan penting terhadap perasaan negatif remaja. Beberapa alasan mengenai faktor akademik seperti kesulitan memahami materi, banyak tugas-tugas sekolah, tidak dapat bertanya langsung kepada guru dan teman, pada akhirnya menimbulkan kecemasan pada beberapa remaja akan masa depannya.

Penelitian ini juga meninjau sumber-sumber gangguan yang menghambat kinerja remaja selama melaksanakan kegiatan sekolah dari rumah. Ditemukan hasil bahwa gangguan sehari-hari atau daily hassles seperti school hassles, resource hassles, family hassles, peer hassles, dan neighborhood hassles dikeluhkan remaja sebagai faktor yang 
menghambat kelancaran kegiatan sekolah dari rumah. Tuntutan dari sekolah atau school hassles merupakan hambatan yang paling sering dirasakan remaja, seperti penjelasan yang kurang dapat dipahami, instruksi tugas kurang jelas, dan tugas yang dirasa terlalu banyak. Temuan lain yang cukup banyak dirasakan remaja sebagai hambatan adalah ketersediaan akses sumber daya atau resource hassels, seperti akses internet dan kuota. Salah satu partisipan dalam penelitian ini mengemukakan bahwa kendala utama selama melaksanakan sekolah dari rumah adalah tidak tersedianya alat komunikasi handphone. Meskipun demikian, terdapat usaha dari partisipan untuk tetap menjalankan kegiatan sekolah dari rumah, yaitu dengan menyewa handphone dari tetangga di dekat rumahnya.

Daily hassles merupakan hal-hal yang sering kali tidak disadari remaja, namun berkontribusi pada peningkatan distress psikologis (Allen, dkk., 1995). Menurut Lazarus (1981) daily hassles atau gangguan sehari-hari adalah sebuah tuntutan yang membuat frustrasi dan menyusahkan dan pada derajat tertentu bersinggungan dengan kegiatan sehari-hari remaja. Gangguan sehari-hari terbukti berhubungan dengan penyakit somatik dan memperparah major life event apabila pengalaman tersebut diikuti dengan daily hassles. Oleh sebab itu, dalam melaksanakan kegiatan sekolah dari rumah, remaja perlu mendapat perhatian lebih karena dampak pandemi COVID-19 disertai dengan daily hassles membuat remaja rentan mengalami distres psikologis dan gangguan fisik lainnya.

Peneliti berharap hasil temuan di dalam penelitian ini dapat digunakan sebagai tambahan informasi untuk meminimalisir gangguan-gangguan yang dirasakan remaja dalam melaksanakan kegiatan sekolah dari rumah di masa mendatang. Peneliti juga berharap pemerintah, orang tua, dan orang-orang yang dekat dengan remaja dapat memberikan pendampingan psikologis yang tepat dengan memperhatikan aspek psikologis lainnya untuk mengurangi dampak negatif pandemi COVID-19 pada remaja.

\section{Kesimpulan}

Pada akhirnya, kebijakan sekolah dari rumah merupakan pilihan terbaik yang dapat dilakukan oleh negara untuk mencegah penyebaran COVID-19 dikalangan remaja. Meskipun demikian, muncul berbagai dampak negatif yang dirasakan remaja selama melaksanakan kegiatan sekolah dari rumah ini. Penelitian ini berusaha untuk memberikan gambaran kondisi psikologis remaja awal di Indonesia yang melaksanakan kegiatan sekolah dari rumah akibat pandemi COVID-19. Selama sekolah dari rumah terdapat tiga perasaan terbanyak yang dirasakan remaja yaitu bosan, lelah, dan senang. Meskipun demikian, perasaan negatif seperti bosan, lelah, sedih, takut, khawatir, dan kecewa lebih banyak dirasakan remaja dibandingkan dengan perasaan positif. Kurangnya interaksi dengan orang lain dan kegiatan akademik yang berjalan tidak lancar menjadi penyebab utama perasaan negatif muncul. Pemerintah perlu menindaklanjuti dampak negatif kegiatan sekolah dari rumah untuk mencegah timbulnya masalah psikologis yang lebih berat pada remaja di masa mendatang. 
Penelitian ini memiliki keterbatasan terkait dengan remaja yang merasakan emosi positif yaitu senang selama sekolah dari rumah. Seperti yang telah dipelajari bahwa interaksi di luar rumah menjadi hal penting bagi remaja. Selain itu, selama sekolah dari rumah ditemukan banyak stressor yang berkontribusi pada peningkatan distres psikologis remaja. Perlu kajian lebih lanjut mengenai pengalaman perasaan positif yang dirasakan beberapa remaja selama melaksanakan kegiatan sekolah dari rumah. Penelitian selanjutnya, dapat menyertakan variabel keluarga untuk meninjau kembali apakah terdapat pengaruh keluarga terhadap kondisi psikologis remaja selama sekolah dari rumah.

\section{Daftar Pustaka}

De Goede, I. H., Branje, S. J., Delsing, M. J., \& Meeus, W. H. (2009). Linkages over time between adolescents' relationships with parents and friends. Journal of youth and adolescence, 38(10), 1304-1315. https://doi.org/10.1007/s10964-009-9403-2

Fleming, M. (2005). Adolescent autonomy: Desire, achievement and disobeying parents between early and late adolescence. Australian Journal of Education and Developmental Psychology, 5, 1-16.

Imran, N., Aamer, I., Sharif, M. I., Bodla, Z. H., \& Naveed, S. (2020). Psychological burden of quarantine in children and adolescents: A rapid systematic review and proposed solutions. Pakistan journal of medical sciences, 36(5), 1106-1116. https://doi.org/10.12669/pjms.36.5.3088

Giallonardo, V., dkk. (2020). The impact of quarantine and physical distancing following COVID-19 on mental health: Study protocol of a multicentric italian population trial. Frontiers in Psychiatry, 533(11), 1-10, doi: 10.3389/fpsyt.2020.00533

Guessoum, dkk. (2020). Adolescent psychiatric disorders during the COVID-19 pandemic and lockdown. Psychiatry Research, 291, 1-6. https://doi.org/10.1016/j.psychres.2020.113264

Huang, C., dkk. (2020). Clinical features of patients infected with 2019 novel coronavirus in Wuhan, China. The Lancet, 395 (10223), 497-506. https://doi.org/10.1016/S0140-6736(20) 30183-5.

Jackson, J., \& Cochran, S. (1991). Loneliness and psychological distress. The Journal of Psychology, 125. 257-62. 10.1080/00223980.1991.10543289.

Kementerian Pendidikan dan Kebudayaan. (2020). SIARAN PERS Nomor: 137/sipres/A6/VI/2020. Diunduh dari https://www.kemdikbud.go.id/main/blog/2020/06/panduan-penyelenggaraanpembelajaran-pada-tahun-ajaran-dan-tahun-akademik-baru-di-masa-covid19

Kementerian Kesehatan Republik Indonesia., \& Gerakan Masyarakat Hidup Sehat. (2020). COVID-19 dalam Angka Kondisi 26 Juni 2020. Diunduh dari www.kemenkes.go.id. 
Kementerian Kesehatan Republik Indonesia. (2020, Mei 4). Penetapan Pembatasan Sosial Berskala Besar PSBB di Sejumlah Wilayah di Indonesia. Pusat Krisis Kesehatan. Diunduh dari http://pusatkrisis.kemkes.go.id/penetapan-pembatasan-sosialberskala-besar-psbb-di-sejumlah-wilayah-di-indonesia.

Kontoangelos, K., Economou, M., \& Papageorgiou, C. (2020). Mental health effects of COVID-19 pandemia: A review of clinical and psychological traits. Psychiatry Investig, 17(6): 491-505. doi: 10.30773/pi.2020.0161

Lazarus, R.S., \& Folkman, S. (1984). Stress, appraisal, and coping. New York: Springer.

Leung, C.C., Lam, T.H., \& Cheng, K.K. (2020). Mass masking in the COVID-19 Epidemic: People need guidance. The Lancet, 395(10228), 945-947.

Lee, J. (2020). Mental health effect of school closures during COVID-19. Lancet Child Adolescent Health, 395, 912-20. https://doi.org/10.1016/S2352-4642(20)301097.

Liang, L., DKK. (2020). The effect of COVID-19 on youth mental health. Psychiatric Quarterly, 91, 841-852. https://doi.org/10.1007/s11126-020-09744-3.

Loades M.E, dkk. (2020). Rapid systematic review: The impact of social isolation and loneliness on the mental health of children and adolescents in the context of COVID-19. $J$ Am Acad Child Adolesc Psychiatry, 3. https://doi.org/10.1016/j.jaac.2020.05.009.

Miller, P.H. (2011). Theories of developmental psychology (5th ed). New York: Worth Publishers.

Marotz, L.R. \& Ellen, K.E. (2013). Developmental profiles: Pre-Birth through adolescence (7th ed). California: Wadsworth.

O’Malley, C., Langtom, S., Anderson, A., Sneddon, G.D., \& Bruce, V. (1996). Comparison of face-to-face and video-mediated interaction. Interacting with Computers, 8(2), 177-192.

Orben, A., Tomova, L., \& Blackmore, S.J. (2020). The effects of social deprivation on adolescent development and mental health. Lancent Child Adolesc Health, 4 (8), 634-640. doi: 10.1016/S2352-4642(20)30186-3.

Orgilés, M., Morales, A., Delvecchio, E., Mazzeschi, C., \& Espada, J.P. (2020). Immediate psychological effects of the COVID-19 quarantine in youth from Italy and Spain. 10.31234/osf.io/5bpfz.

Rana, R. A., \& Mahmood, N. (2010). The relationship between test anxiety and academic achievement. Bull. Educ. Res. 32, 63-74.

Rathore M. K. \& Sangwan S. (2015). Academic performance of adolescents: An indicator of prosperous life. Advance research journal of social science, 6(2): 203-208. 
Saurabh, K., \& Ranjan, S. (2020). Compliance and Psychological Impact of Quarantine in Children and Adolescents due to Covid-19 Pandemic. Indian journal of pediatrics, 87(7), 532-536. https://doi.org/10.1007/s12098-020-03347-3

Seidman, E., dkk. (1995). Development and validation of adolescent perceived microsystem scales: social support, daily hassles, and involvement. American Journal of Community Psychology, 23 (3), 355-388.

Swick, S.D., Jellinek, M.S., Dechant, E., Jellinek, M.S., Belluck, J. (2002). Children of victims of September 11th: A perspective on the emotional and developmental challenges they face and how to help meet them. Journal of Developmental and Behavioral Pediatrics: JDBP, $23 \quad$ (5), 378-384. https://doi.org/10.1097/00004703- 200210000-00013

Wu, Y-Chi., Chen, C-Sung., Chan, Y-Jiun. (2020). The outbreak of COVID-19: an overview. Journal of the Chinese Medical Association. 83 (3), 217-220. doi: 10.1097/JCMA.0000000000000270

Wang, G., Zhang, Y., Zhao, J., Zhang, J., \& Jiang, F. (2020). Mitigate the effects of home confinement on children during the COVID-19 outbreak. The Lancet, 395(10228), 945-947.

Wang, S., Wen, X., Dong, Y., Liu, B., \& Cui, M. (2020). Psychological influence of coronavirus disease 2019 (COVID-19) pandemic on the general public, medical workers, and patients with mental disorders and its countermeasures.

WHO, 2020, Juni 4. Coronavirus disease (COVID-19) Situation Report - 136. Diunduh dari https:// www.who.int/docs/default-source/coronaviruse/situationreports/20200604-covid19-sitrep-136.pdf?sfvrsn=fd36550b_2. 